\title{
Response
}

\section{A response from Francis Watson}

It is an honour and a pleasure to respond to the comments of J. Louis Martyn and Troels Engberg-Pedersen. Both of them have read my book with care, and have presented many of its central emphases with clarity and insight. The questions they raise are pertinent ones - as one would expect from the authors of two of the most interesting and innovative works of Pauline scholarship to have been published in recent years. I refer to Martyn's commentary on Galatians and Engberg-Pedersen's Paul and the Stoics - both, in their different ways, the kind of ground-breaking work that keeps the field of Pauline studies from succumbing entirely to an endless rehearsal of already familiar positions. I also note in passing that my two reviewers probably differ more sharply from each other than either of them does from me. It is not easy to harmonise Martyn's apocalyptic Paul with Engberg-Pedersen's Stoic one, and the difference tends to focus on issues of divine agency which recur in their responses to my own work.

Martyn is generous in his praise for my book, but requests a sequel in which the same ground (Pauline scriptural interpretation) is covered from a different perspective (actual inner-churchly debate, as opposed to fictitious 'conversations' with other Jewish interpreters of scripture from the Second Temple period). I shall return to Martyn's blueprint for a sequel in due course. In contrast, Engberg-Pedersen (henceforth TEP) is much more critical, concluding that 'Francis Watson's big idea is a miss', although he is kind enough to add: 'But what a splendid miss!' When TEP entitles his piece 'Once More a Lutheran Paul?' he immediately signals that, in his view, my book is rather seriously flawed. (Readers of this journal should be aware that, in the small world of Pauline studies, 'Lutheran' is currently employed as a term of abuse.) With its talk of the 'unconditional' character of divine saving agency, my book allegedly turns the clock back to the bad old days before E. P. Sanders, J. D. G. Dunn and the so-called 'new perspective on Paul'. Purporting to be contemporary, with its fashionable talk of 'intertextuality' and of early Christianity as one of a number of 'Judaisms', my book seems to TEP to be thoroughly reactionary in what he takes to be its central theme. 'Once more' indicates a step backward rather than a step forward. In sharp contrast, Martyn (JLM) anticipates for my book 'an extraordinary effect ... on the future of biblical study'. How are these totally different evaluations to be explained?

The difference evidently derives from my reviewers' respective hermeneutical assumptions. JLM is in broad sympathy with the hermeneutical 
decisions underlying my book, whereas TEP is not. In drawing out the reasons for TEP's unease, I shall identify a methodological divide within Pauline studies over fundamental questions of reading strategies and priorities.

\section{Troels Engberg-Pedersen: the exegete's code}

According to TEP, 'the one thing that is fundamentally lacking [in Watson's book] is exegesis of the Pauline letters' - although this is admittedly 'a startling claim to make about a book that spends so much time on extensive, painstaking and often very illuminating analysis of individual Pauline passages'. A startling claim indeed. I was myself much startled when I first read it, having assumed until then that my book necessarily contained a good deal of exegesis of the Pauline letters, an assumption apparently confirmed by the scriptural index. But now I learned that exegesis is 'lacking' here; indeed (still worse) that it is 'fundamentally lacking'. What went wrong? How did so glaring a deficiency escape the author's attention? Has TEP here succeeded in fulfilling the well-known demand that the interpreter should understand the author better than he understands himself?

Hardly. A more plausible interpretation of TEP's startling claim is that he and I work with different models of what exegesis is. I venture to suggest that his model implies the following four rules about the right way to interpret a pauline text:

Rule 1: An individual Pauline passage should under no circumstances be considered without reference to its wider literary context.

Rule 2: A Pauline text should always be understood in relation to its 'rhetorical situation', that is, the situation of its addressees as construed by Paul.

Rule 2: We must distinguish sharply between Paul's (sometimes perverse) approach to scriptural interpretation and our own.

Rule 4: We should be alert to other exegetes' tendency to impose their own preconceptions on Paul's texts, thereby fundamentally misreading them.

It is (so it seems to me) on the basis of hermeneutical rules such as these that TEP weighs my attempts at Pauline exegesis and finds them wanting. For my part, I regard these rules as doctrinaire, restrictive and unwarranted. I can best illustrate the depth of the hermeneutical disagreement by discussing examples of each rule as it operates in TEP's article.

\section{Rule 1}

In chapter 6 of my book I discuss Paul's reading of the Exodus story of Moses's veiling, in 2 Cor 3:6-18. TEP finds fault with my focus on this 
specific passage, on the grounds that it is "quite impossible to say that one understands 2 Cor 3:6-18 unless one has considered the way it fits into at least 3:1-4:6'. Plausible though it might seem, this claim is largely specious. If it were true, then one would have to add that it is impossible to understand 3:1-4:6 unless one considers how this section in turn fits into (say) 2:14$6: 13$, and so on, until we arrived at 1:1-13:13. Every interpretation of a specific passage would require a laborious preliminary analysis of the entire text. There are plenty of dull monographs that proceed in exactly that way, but they are hardly a model of good exegetical practice. If TEP thinks that my reading of the Exodus-related material is impaired by lack of attention to the surrounding passages, he should explain how and to what extent this is the case, rather than insinuating some breach of exegetical propriety.

\section{Rule 2}

A comparable claim is made about the absolute significance of the original historical context. In reconstructing the intricate logic of Paul's appeal to a scriptural text in Galatians, I should (according to TEP) have considered first how the text was intended to function within the Galatian situation. And so another laborious preliminary analysis is required. All the usual topics have to be paraded once again. Where were the Galatians? Who were Paul's opponents? What was their message? As a matter of fact, I have my own views on all these issues, and have expressed them in print elsewhere. But I cannot accept TEP's assumption that it is somehow compulsory to discuss these matters every time one wishes to say something about Galatians. There is no such thing as 'the original historical context'. Whether literary or historical, a context is a flexible entity constructed by the interpreter for whatever interpretative purposes are in view. My own preferred 'original historical context' was one in which Paul's readings of Genesis or Deuteronomy were compared and contrasted with other roughly contemporary Jewish readings of these same texts. Why should an 'original historical context' of Paul's scriptural interpretation in Galatians not take this form?

\section{Rule 3}

For TEP it is important to insist that certain Pauline readings of scripture 'verge... on being a perversity'. We are to lend our backing to those of Paul's Jewish contemporaries who tell him: 'Excuse us, that is just wrong'. Who are these Jewish contemporaries, lining up to defend the plain sense of scripture in opposition to Pauline caprice? Perhaps they are Pharisees, as Paul himself had been, resolutely maintaining that their doctrine of resurrection is firmly grounded in the Torah. Or perhaps they are members of the Qumran community, searching the prophetic texts to find themselves and 
their opponents encoded there. Or perhaps they are Alexandrians, convinced that Plato was a disciple of Moses and that his most characteristic doctrines are already to be found in the work of his greater predecessor. Such people have every reason to say to Paul, 'Excuse us, that is just wrong'. But there is no reason why we should take their side against Paul. What we can do is to try to recover the logic of these divergent readings of scripture, Pauline and otherwise, on the basis of a nuanced and flexible understanding of the act of reading according to which meaning arises out of the interaction of reader and text. These ancient scriptural readings remind us that texts themselves are more complex and many-sided than we are accustomed to think, that they are the site of a semantic potential not easily reducible to any singular meaning or significance.

\section{Rule 4}

TEP alleges that exegetes such as myself are in the disastrous habit of imposing our own presuppositions on Paul's texts, thereby seriously misreading them. According to TEP, my book is based on an antithesis between divine and human agency which 'to the best of my understanding is to be found neither in scripture itself nor in Paul'; I myself have imposed it on the texts. So, yet another serious breach of the exegete's code of good practice, as drafted by TEP. The claim to have imposed my own preconceptions arises largely from my treatment of Paul's much-debated faith/works antithesis. I argue on exegetical grounds (1) that this should not be understood (as it often has been) as entailing a maximal account of divine agency at the expense of human in the one case, and of human agency at the expense of divine in the other; and (2) that the relation of divine to human agency is nevertheless understood differently on the two sides of the antithesis. 'Faith' speaks of a communal life founded on and oriented towards the comprehensive reality of the divine saving action in Christ, of which it is the acknowledgement; 'works' speaks of a communal life oriented towards the Torah's prescriptions and prohibitions for the covenant people; and the relation of divine to human agency is understood differently within these two communal contexts. My reading of Paul's language may or may not be correct. The point here is that it does not further the exegetical debate in any way to be told (as if this were obvious to everyone except myself) that the antithesis as I understand it 'is to be found neither in scripture itself nor in Paul', and that I myself have imposed it on the texts. Exegetical argument should be met with exegetical counter-arguments, not with airily dismissive references to preconceptions.

If TEP finds genuine exegesis to be 'fundamentally lacking' in my readings of Paul, I suggest that the problem is more his than mine. His code of 
exegetical practice is indeed a narrow one. I am inclined to see in it just another well-meaning bureaucratic attempt to regulate and restrict the diversity of actual practice, a typical product of contemporary managerial culture. Its over-prescriptive claim to be able to differentiate clearly between good and bad practice is, at the very least, highly contestable.

\section{J. Louis Martyn: the sequel}

Fortunately, J. Louis Martyn does not share his colleague's enthusiasm for codes of exegetical practice. Instead, he requests a sequel in which attention is focused on Pauline scriptural interpretation within the context of the early church. How did Paul read scripture with and against his various dialoguepartners in Jerusalem, Antioch, Galatia or Corinth? There is no implication that this question should really have been attended to first, before broadening the picture out to include the non-Christian interpretative texts. The proposed sequel would be genuinely a sequel, not belated prolegomena. It would be dependent on the first volume, which it would complement and strengthen. It would also identify limitations and weaknesses in the first volume, but not in such a way as to suggest that the first volume was fundamentally misconceived or 'a splendid miss'.

In principle, I like this proposal. As it happens, I am currently completing work on a project that goes some way towards meeting JLM's specifications. Yet these specifications are undeniably stringent. We are to reconstruct reallife arguments about scripture in Jerusalem, Antioch, Galatia and Corinth. And what of Rome? If it fails to treat the intense engagement with scripture that fills the pages of Paul's letter to the Romans, the sequel will be a mere torso. Even if Paul has not yet been to Rome, his letter may be seen as an intervention in a debate among Roman Christians about scripture and scripturally shaped practice (cf. Rom. 14). Will the sequel shed more or less or just different light on Paul's texts than its predecessor? That is impossible to say in advance. Yet, if carried out in accordance with JLM's specifications, the sequel will soon face some fairly intractable difficulties.

The task is to overhear Paul's conversations about scripture with his fellow Christians. With this in mind, let us visit the church at Corinth on the occasion when Paul's (so-called) first letter is being read to the assembled community by Timothy, its bearer. (Those instructed by JLM's exceptional Galatians commentary will not find anything untoward in such a thoughtexperiment.) The reader has reached the point in Paul's text where the apostle is reaffirming the doctrine of the resurrection, and members of the community who 'say there is no resurrection' may readily be identified by their visible discomfort. The apostle proceeds to develop a distinction between the 'psychic' body and the 'pneumatic' one, a body animated by soul 
in contrast to one animated by spirit. The terminology may be unexpected, but it has been suggested by scripture. Paul quotes from Genesis 2:7 and draws far-reaching conclusions from this text:

If there is an ensouled body, there is also a spiritual body. Thus it is written: 'The first man Adam became a living soul [eis psuchēn zōsan]'; the last Adam, life-giving spirit. But the spiritual does not come first; rather, the ensouled comes first, then the spiritual. The first human is from the ground, a creature of dust, the second human is from heaven ... (1 Cor 15:44-7)

Here, something is being affirmed, but something is also being denied: 'The spiritual does not come first; rather, the ensouled comes first, then the spiritual' (v. 46). As Timothy reads on, it becomes clear that the apostle did not elaborate the denial any further but intended it only as a passing remark. It is difficult to know what he meant by it. Did he mean to criticise a belief held in the Corinthian congregation, that the spiritual human (= Christ?) preceded the ensouled, earthy, physical one? The deniers of the resurrection are clearly present within the assembled company. Their body-language gave them away, as did the meaningful looks that passed between other members of the audience as Timothy read the words: 'But if Christ is proclaimed as risen from the dead, how can some of you say that there is no resurrection of the dead?' (v. 12). But no such unambiguous reactions were perceptible at the moment when Paul denied the priority of the spiritual. It was just a passing remark. We cannot tell if it meant little or much to the Corinthian Christians.

We are on firmer ground if we locate Paul's denial in the context of a dialogue not with Corinth but with Alexandria. The claim that the spiritual human precedes the physical one derives from the double account of the creation of humanity in Genesis 1-2, read along Platonic lines. The physical human is a copy of the noncorporeal, invisible archetype created in accordance with the divine image. In his treatise on the Genesis creation stories, Philo has this to say about the text that Paul too cites:

After this, [Moses] says: 'God formed the man by taking dust from the ground, and breathed into his face the breath of life'. By this he clearly shows that there is a fundamental difference between the man here said to have been 'formed' and the one created first [gegonotos proteron], 'after the image of God'. For the 'formed' man is perceptible to the senses, displaying distinctive characteristics, body and soul, male or female, mortal by nature; whereas the one who 'according to the image' is an 
idea, type or seal, perceptible to the mind, without body, neither male nor female, immortal by nature. (De opificio mundi 134)

It is some such exegesis of Genesis 2:7 (with 1:26-7) that Paul appears to be refuting when he states that 'the spiritual does not come first; rather, the ensouled comes first, then the spiritual'. Christ is not the archetype of humanity but humanity's eschatological goal. The Genesis exegesis in question is probably pre-Philonic, so Paul need not have known specifically of Philo. But he must have known the exegesis itself, without which his denial of the priority of the spiritual is difficult to explain. Here, he is in dialogue with Alexandria. The question is whether he is also in dialogue with Corinth, as JLM's proposed sequel requires him to be.

It is possible to imagine how the Alexandrian exegesis might have become known at Corinth. Paul writes to the church there in the aftermath of a visit from Apollos, a celebrated Alexandrian exegete who is probably the ultimate target of the critique of 'wisdom' in 1 Corinthians 1 . Was a christianised version of the Alexandrian Genesis exegesis part of the 'wisdom' that Apollos communicated to the Corinthians? Did he identify the 'man according to the image' of Genesis 1 with a pre-existent Christ? Was the non-corporeality of this Christ a factor in the Corinthian rejection of resurrection? These are intriguing possibilities; but they are no more than that. We just do not know from Paul's passing reference whether the Alexandrian exegesis was current at Corinth.

The implications for JLM's proposed sequel to my book on Pauline hermeneutics are very considerable, and they are also somewhat discouraging. As we have seen, we are in a position to develop a promising comparison between the Genesis interpretations of Paul's letter and of Philo's treatise. Although Paul is aware of the Alexandrian Genesis exegesis, he probably has no direct link to Philo. So, from a methodological point of view, this comparison would remain within the framework of Paul and the Hermeneutics of Faith, and would not advance beyond it. In JLM's language, we would remain in the sphere of "metaphorical conversation among inanimate texts', and would not have moved on to 'conversations in which Paul was literally involved with other flesh-and-blood interpreters of scripture in his own time and place'. If it is literal conversations about scripture that we want, then we will be obliged to make as plausible a case as possible for the currency of the Alexandrian exegesis at Corinth. With the help of Apollos, that could be attempted. And yet it does seem that the metaphorical conversation among inanimate texts is more securely grounded in historical reality than the literal conversation about Genesis 1-2 that may or may not have taken place in the course of Paul's interaction with the church at Corinth. And the same 
scottish journal of theology

uncertainty would surely also prevail in the other literal conversations about scripture to which JLM invites us to attend - in Jerusalem, in Antioch and in Galatia. Striving for greater historical concreteness, we leave the solid ground of extant texts and construct more or less plausible speculations about what might have been the case.

My two reviewers raise many other questions that I cannot deal with here. I am grateful to both for the generosity of spirit they maintain throughout, even in criticisms forcefully expressed or gently hinted at. They demonstrate that conversation about scripture, with other flesh-and-blood interpreters, in our own time and place, is still a going concern; and also that the sheer enjoyment of the conversation is not incompatible with its existential urgency.

Francis Watson

School of Divinity, History and Philosophy, University of Aberdeen, King's College, Aberdeen AB24 3UB

f.b.watson@abdn.ac.uk 